\title{
SECURITY AS A POWER ELEMENT WITHIN CONTEMPORARY INTERNATIONAL RELATIONS
}

\author{
Gabriel GABOR \\ gaborsmg@yahoo.com \\ “LUCIAN BLAGA” UNIVERSITY, SIBIU, ROMANIA
}

\begin{abstract}
Today, more than ever, in a globalized and constantly changing world, Europe has to face new stakes and challenges. The globalization, climate change, power supply and the new threats to security are challenges that Europe of the XXIst century has to cope with. The early XXIst century coincides with a new era in the international politics, the future evolution of the worls and the new international order, with the economy and security being the central spots.
\end{abstract}

\section{Keywords}

Security, power, international relations, contemporary world

\section{Introduction}

Today's world, ideologically and strategically less confliction, is heading to a multi-polar global system, with a globalized and globalizing economy, characterized by the rising of the new powers and an increased influence of the non-state actors.

The spectrum of the international relations is permanently reconfigured by the foreign affairs policy of the states, determined by their national interests, by their political culture and even by their successive positions within the system of international relations. The development of the foreign affairs policy starts from the identification of national interests and priorities, from the strong assessment of long term global and regional thematic trends, and from the strategic view over the methods and instruments that can be used to accomplish these interests and priorities. An important aspect, relevant for the evolution of the inter-states relations is given by the internal dimension of the foreign affairs policies. Restoring the international through a new configuration of centers of power is placed between the major changes within the global security ,disorder” [1].

\section{Theories of Power in International Relations \\ The current international context is marked by profound mutations of the global architectures in the field of security that leads to new responsibilities and generates complex challenges. There have been new actors on the international scene and that has lead to a significant increase in the interdependence between states. Still, the experts believe that "...the national state still continues to be the most important player of the contemporary world" [2].}


According to Robert Kogan, the world has not changed, "nations are as powerful as always and so are the nationalistic ambitions, passions and the competition between nations that has shaped the history" [3].

The current security environment is extremely dynamic, and continuously changing from a bi-polar global system where the US and USSR had the role of superpowers and the regional powers had a reduced power, to a multi-polar system where we can see superpowers - USA, regional powers-China, Russia, Japan, India and re-united Korea and states or non-state entities that have developed a great capacity in a relative small and limited domain, with the possibility to influence, sometimes decisively but on a short-term the evolution of the international environment.

Globalization creates a new context for using national power formally and informally. Security has to be the main ,objective of using the national power" [4], and for this, some political approaches able to enforce the control of insecurity are necessary.

The means for enforcing the power of a state consist of the resources and the means used to accomplish its strategic objectives, to defend its national interests or to enforce its own interests in areas of strategic importance. In general, it is considered that states have four essential instruments of power: diplomacy, information, military and economy.

The world of the XXI ${ }^{\text {st }}$ century brings profound changes in cycles significantly reduced compared to the last century. Within this context, nowadays a state can exercise its power and conquer an area of strategic interest using IT means: cyber warfare is a reality of the modern world. Within this peace-conflict paradigm, wars are no longer declared; a war can be carried against a state or a non-state enemy without even the later to know, but it will definitely feel the consequences. Another factor of power available for the state is the power resource: that who has the power resource has the real power and he can use it.
It can be stated that ,change is the word that characterizes the security environment of the XXI ${ }^{s t}$ century. Alongside the classic forms of global and regional vulnerabilities and risks, there are other phenomena such as globalization and fragmentation. Traditional tension , hotbeds" are still present, but their development is now influenced by new unconventional and trans-border risks such as terrorism, organized crime or proliferation of weapons of mass destruction.

The new security environment becomes flexible, constructions of all kind can be accomplished, organizations and reorganizations, depending on certain trends, but also on the dynamic of interests (...) at the level of political powers" [5]. (...) What makes the contemporary process of globalization different from the previous integrationist processes are the scale (previously regional, now global), the rhythm of changes required by the speed of information and vectors of transfer and relying, more that before, on the technological progress with immediate impact over the day-to-day life.

"Power as a word has a great semantics abundance and it is used for an extremely diversified area of social, economical and military reality. Most of the definitions have in common the enforcement of the will by an actor over another; from this perspective, one of the most precise definitions is given by Robert A. Dahl, who sees power as the ability to make others do what otherwise they wouldn't, but this is achievable only if that actor has the capacity to do it, in other words, if the actor has the potential. Traditionally, the power potential was estimated by summing up the human resources, the economic resources, the territorial area, the strength and quality of military forces". "This concept of power has been long debated by the majority of disciplines either we talk about sociology, political science or international policy".

At present, security, as well as power and wealth, tends to transfer itself from the state and its institutions to organizations or even persons. There are companies, persons and organizations that have a comparative 
security or even superior to that of their own states and governments. This is possible because those companies, persons and organizations own or control bigger resources that those of some states. In this way, the great multinational corporations can start a war and can change governments, as well as during the Middle Age the powerful barons were able to change the kings or subdue territories completely. If we can still talk about a polarization of the world ruled by great state powers such as the USA, Russia, China, the EU, in the near future we will talk about a global polarization ruled by great corporations and multinational non-governmental organizations such as the UN, IMF, EXON, Microsoft, the federal reserves of the Americas, GAZPROM, etc. We do not know any more which ones of the local/regional/ethnic conflicts that worsen unexpectedly have only local causes and which ones are induced or encouraged/fed by corporate and non-governmental financial and economic interests.

The international security environment is in a permanent transition. Some changes are predictable and linear, whether they arise from the objective development of the security environment or they are the result of strategies and programmes. Others have unthinkable features, of essential discontinuity, seismic type, and they come together with a dose of uncertainty significant in its nature, proportion and duration.

\section{Developments in the Security Environment}

The evolution of the security environment has known profound transformations through the enlargement of the two international organizations, NATO and EU, as well as through the re-sizing and re-consideration of their role and place within the economy and management of the regional and global security and stability. The international security and stability can no longer be thought of as the exclusive privilege of some states and it is no longer limited to a small bunch of problems such as war and peace. These are the concern of the international organizations and some state and non-state actors who share common values and ideals.

In the context of favorable conditions for the general process of integration, highlighted by the steps taken to build a new security architecture and to re-evaluate the relations between states and to recognize the political dialogue and partnership as essential elements for solving sensitive situations, we witness the recrudescence of asymmetric threats. Among them, the neo-terrorism gets global valences by its increased dangerousness and spreading area, and together with organized crime and proliferation of weapons of mass destruction, they are a major threat to global and regional security.

The persistence of some areas of security instability encouraged by the existence of some dictatorial political regimes and grafted on the deepening of some socio-economic inequalities, leads to the activation of some latent crisis and the generation of new ones with regional and local impact. These facts, corroborated with the new threats and challenges, bring to light crisis that the international community and NATO in particular identify, analyze and monitor. In this context, there are adequate strategies, ways, capacities and instruments to provide an efficient management for these crises.

In the new century, there are more and more debates about strategic re-positioning, reconfigurations of the security environment, great powers - winners and losers, new geopolitics and serious threats to the environment, aspects that are often approached as some shapes without substance and they range among narrowminded perceptions, inadequate to face the major challenges. At the early $\mathrm{XXI}^{\text {st }}$ century, a challenging behavior, detrimental for co-operation, is still promoted, as the first proof for self-affirmation ambitions and for those imperialistic ones [6].

It is deeply rooted in our minds that life in society is a fight for living, where the 
strong win and aggressive approach becomes a goal. Inevitably, we as individuals have to face the legacies of the $\mathrm{XX}^{\text {th }}$ century where the fighting for supremacy and power have been only the pretexts to fight for influence.

Changes within the strategic environment of security, characterized by major changes such as an unprecedented dynamic, by numerous events, tempestuous and difficult to predict and by a randomly evolution of the tensions, challenges and risks generating crisis and conflicts, represent the fundamental elements for the political and military analysts, the leadership of the states, different organizations and other international actors in re-defining their visions over the defense and security issues.

Although collective or individual efforts of the states and international organizations toward maintaining global and regional security and stability rely on dialogue, and as such, the use of peaceful, non-violent, political, diplomatic, economic means proved to be more and more efficient, still the military instruments, in their extreme forms of manifestation, including war, often remain the last resort even with the agreement and consensus of the international community, to solve disputes that involves states as well as non-state actors.

The current security environment is different from the old climate with regard to new elements of content, structure, distribution and evolution trends:

- if in the old environment insecurity and instability were nearly the same in all geographical areas, in the current environment, the European space would stand out from the one in Asia, Americas or Africa;

- Threats to Europe's security can come from the outside and that explain the transfer from NATO's collective defense to that of collective security;

- The current security environment has been through a lot of changes with regard to armament strategy which has diminished and the priority of the security strategy is the disarmament and non-proliferation of nuclear technologies and weapons;
- Today, insecurity determined by nuclear weapons is being taken by corruption, religious, national or ethnic conflicts, international terrorism.

State-nations have lived long enough given their nature as depositaries of those forces that try to keep alive the ideological division and intervene over the optimum allocation of the incomes catching at obsolete terms such as national sovereignty. The globalization trends are not imaginary. Some real changes and of great impact have had their place in the world's economy, and they have weakened the state-nations and even encroached upon their sovereignty. But many of these extreme statements of the ultraglobalists are unconvincing. The negative aspect of this type of approach of the international policy is that it approaches the global market first as a new organizational form, barely turned up then as a natural process, entirely separated from the politics and the political decision making process, similarly to other principles of the system.

The researchers of international relations have started to see certain non-state actors as promising factors for progressive social change. Some international organizations have transferred a part of states' duties becoming key-actors in approaching specific collective actions. Scientists have granted a high level of reliance to such organizations that they considered able to contribute to the development of a peaceful world, right, economically developed and ecologically healthy. In fact, many researchers see the non-state actors as a setting up global democracy, where the transnational civil society offers a non-state form of representation at global level.

Non-state actors are non-sovereign entities that exert their social, political and economic power significantly with a great deal of influence not only at national level but also at international level. Proliferation of non-state actors has recently lead some international relations observers to the conclusion that states are less important while non-state actors increase their status and influence. 
This century evolves toward the multipolarity of the world, as an intermediate stage of globalization where the lead taking and recognition of the new planetary leaders build up as a real competition, and the increased inter-dependency and interaction between states, possible as a result of the fall of the communist system, intensify the dialogue between civilizations and facilitate the transfer of civilization from the West to the Est.

The global integration is a factor known by years within the international relations, having deep roots in history, the hypotheses of a growth of interdependencies at global level, at the same time with the development of some international organizations able to help implement this process, seem to get substance especially after the World War II.

Both globalization and regionalization have the same objectives as to promote peace and to provide a high standard of living, both of them supporting the idea that the current international system should be modified in the way that state-nations should give up a part of their own sovereignty in favor of some larger economical and political units. This trend of interdependencies' growth at global level has created an increase in trans-border issues which require global solutions.

No matter how strong the trends of globalization would be, it does not stop to be a part of politics or to be governed by politics. Beyond the cosmopolitan order of the global market there is a territorial one belonging to the international system of states and another hegemonic one belonging to the system of transnational ruling, and these are types of leaderships of the global market that play the role of mediator between states and markets.

Globalization forces the new security environment to accept new trends of development, reconsider, reconfigure and reinterpret some concepts such as the security one, the national sovereignty, the inter-dependency, the integrity from the classic type in the modern period and the $\mathrm{XX}^{\text {th }}$ century to the current one [7].
The new security environment goes through a re-hierarchy of its dimensions; those of economic, political, informational or influential nature within the international relations surpass those of military nature with a decisive status. Even the concept of super-power changes meaning that a superpower has to be powerful from economic, political, military, informational, technological and scientific perspective. With all the fluctuations and infringements, the major, dominant trend of the current evolution of the security environment is its enlargement, stabilization and democratization.

Also, "Globalization imposes the new security environment new trends of development, re-consideration and re-interpretation of concepts like security, national sovereignty, and inter-dependency, integrity from the classic form of the modern period and that of the $X X^{\text {th }}$ century to the current one" [8].

\section{Conclusions}

Globalization influences the security environment, global pandemics, climate changes, pollution, power resources and any other dimension that can suddenly evolve also brings and has a security component.

Changes within the political arena bring up that, through the efforts of the international community and the involvement of the international security organizations with crisis management objectives, the risk of a major military conflict will keep diminish significantly.

Within this environment politics is considered obstructive, inert, conflicting and retrogressive, a living burden on flexible, creative and viable forces' back in this spontaneous cosmopolite economic order. Trends of globalization are not imaginary.

The stat power is declining. Power is less efficient in these basic problems that the market itself has never been able to care of: protection against violence, stable currency for trade and investments, clear legal system 
and means to enforce it as well as sufficiency of some public services such as sewerage, water supply, transport and telecommunication infrastructure. It is no wander that the power of the state is less observed and that it misses the old times legitimacy.

\section{Aknowledgement}

This work was possible with the financial support of the Sectorial Operational Programme for Human Resources Development 2007-2013, co-financed by the European Social Fund, under the project number POSDRU/159/1.5/S/138822 with the title "Transnational network of integrated management of intelligent doctoral and postdoctoral research in the fields of Military Science, Security and Intelligence, Public order and National Security - Continuous formation programme for elite researchers - «SmartSPODAS»".

\section{References}

1. Nicolae Dolghin, Geopolitics, Dependencies on energy resources, (Bucharest: National Defence University Publishing House, 2004): 6.

2. Ion Preda, Graţiela Barna, Considerations on Romanian national interests, (Bucharest: National Defence University Publishing House, 2006): 5.

3. Robert Kogan, "End of Dream, Return of Hostorz", in Totead the World, American Strategy after the Bush Doctrine, eds. Melvzn P.Leffer, Jeffrez W.Legro, (Oxford: University Press, 2008): 51.

4. Zbigniew Brzezinski, The great dilema - to dominate or to rule, (Bucharest: Scripta Publishing House, 2005): 213.

5. Dr. Mariana Ancuţ, "Global security within the context of present transformations within the international environment", Land Forces Staff Bulletin, 2 (2009), http://rft.forter.ro/2009 2 t/02-fm/02.htm

6. Fritjof Capra, Momentul Adevărului: ştiinţăă, societate şi cultură, (Bucureşti: Technic Publishing House, 2004): 34.

7. Constantin Noica, Emil Hedeşiu, Gheorghe Toma, International Security under the impact of globalization, (Bucharest: ANI Publishing House, 2007): 29.

8. Ibidem, p. 49.

\section{Bibliography}

The Security Strategy of Romania, (2007).

The National Defense Strategy, (2010).

Noica, Constantin, Emil Hedeşiu, and Gheorghe Toma. International Security under the impact of globalization. Bucharest: ANI Publishing House, 2007.

Capra, Fritjof. Moment of Truth: science, society and culture. Bucharest: Technic Publishing House, 2004.

Ancuţ, Mariana, $\mathrm{PhD}$. "Global Security within the context of present transformations within the international environment". Land Forces Staff Bulletin, 2 (2009).

Dolghin, Nicolae. Geopolitics, Dependencies on energy resources. Bucharest: National Defence University Publishin House, 2004.

Preda, Ion, Graţiela Barna, Considerations on Romanian national interests. Bucharest: National Defence University Publishing House, 2006.

Kogan, Robert. "End of Dream, Return of Hostorz". In Totead the World, American Strategy after the Bush Doctrine, eds. Melvzn P.Leffer, Jeffrez W.Legro. Oxford: University Press, 2008. 
Brzezinski, Zbigniew. The Great Dilemma - to dominate or to rule. Bucharest: Scripta Publishing House, 2005.

http//consilium.europa.eu/infopubl

http://nato.mae.ro

http://viapolitica.eu/

http://huffingtonpost.com/

http://www.guardian.co.uk/

http://ro.wikipedia.org/

www.geopolitic.ro/Revista\%Geopolitical.html

http://rft.forter.ro/2009_2_t/02-fm/02.htm 